\title{
Effect of fire and ecological restoration in gallery forests in the Quilombola Kalunga Territory and the Chapada dos Veadeiros National Park, GO
}

\author{
Gustavo Mariano Rezende ${ }^{1}$, Victória Matos ${ }^{2}$, Jaqueline Orlando ${ }^{2}$, Ingrid Andrade ${ }^{2}$, Alexandre Bonesso \\ Sampaio $^{3}$
}

\author{
${ }^{1}$ Bolsista DTI-B, CNPq, Instituto Chico Mendes de Conservação da Biodiversidade, Brasília, Brasil. \\ ${ }^{2}$ Programa de Voluntariado do Parque Nacional da Chapada dos Veadeiros. \\ ${ }^{3}$ Instituto Chico Mendes de Conservação da Biodiversidade, Brasília, Brasil. \\ ${ }^{*}$ Correspondence: gustavomrezende@gmail.com
}

\begin{abstract}
The actions derived from an integrated fire management (IFM), implemented since 2014 in protected areas in Brazil, particularly in the Cerrado, seek to reduce the area affected by wildfires and to protect fire-sensitive vegetation types. The occurrence of wildfires in riparian gallery forests and wetlands (veredas) can significantly threaten the conservation of these ecosystems as well as their efficiency in the protection of water resources and the provisioning of other ecological services. Wildfires in these vegetation types cause the mortality of palms and trees, causing compositional and structural changes, such as the opening of the canopy. The Chapada dos Veadeiros National Park and the Quilombola Kalunga Territory have seen wildfires take place since 2012, which occasionally affected gallery forests. The goals of this study were (i) to map the areas sensitive to wildfire, specifically gallery forests and veredas, (ii) to monitor natural regeneration in these areas, and (iii) to test different techniques to control invasive species and to restore the vegetation. Eighteen 10x20-m plots were installed, in which the process of natural regeneration taking place and the need for a restoration intervention were characterized. Gallery forests showed a high mortality rate of trees, resulting in a low tree density, with one individual per $105 \mathrm{~m}^{2}$ (95 ind/ha). The soil was predominantly coverd by a few invasive species, such as Melinis minutiflora and Andropogon gayanus (up to $26 \%$ cover). Moreover, the loss of the vegetation promoted soil leaching and erosion. Therefore, the proposed restoration actions include: (i) protecting the terrain contour lines using branches, (ii) direct seeding of forest species from the local pool, and (iii) tree staking for the rapid growth of the vegetation and covering of the soil, as well as to facilitate natural regeneration. Once we understand the processes involved in the recovery of these forests, informational materials covering the restoration techniques used in this project will be produced using an accessible language, so that they can potentially be used by the local communities in affected fire-sensitive areas. Technical materials will also be produced and shared with the managers of protected areas involved in restoration efforts and IFM.
\end{abstract}

Keywords: direct seeding; staking; facilitation of natural regeneration; wildfire. 